\title{
Medicines Australia Code of Conduct: breaches 2019-20
}

\section{Keywords}

Medicines Australia, codes of conduct, drug industry

Aust Prescr 2020;43:210

https://doi.org.au/10.18773/ austprescr.2020.071
The Medicines Australia Code of Conduct guides the promotion of prescription products by pharmaceutical companies. ${ }^{1}$ Each year Medicines Australia publishes a report, from its Code of Conduct Committee, which details all the complaints that have been received about advertising and other promotional activities. In 2019-20 the Code of Conduct Committee finalised five complaints (see Table). These were dealt with under the 18th edition of the Code of Conduct. The current 19th edition was introduced in March 2020. ${ }^{2}$ Four of the five complaints were made by pharmaceutical companies. Two of them involved rival companies complaining about their competitor's influenza vaccine. The one complaint from a health professional related to being featured in a video. While the health professional had been paid for assisting in the production, they had not given written consent for the release of the video.

In four cases there was an appeal against the decisions of the Code of Conduct Committee. One of the appeals was by a company which had made a successful complaint. This appeal resulted in a doubling of the fine that had been imposed as a sanction.

More details about the complaints can be found in the full report on the website of Medicines Australia. ${ }^{3}$

Table Breaches of the Medicines Australia Code of Conduct July 2019 - June 2020

\begin{tabular}{llll}
\hline Company & Brand (generic) name & Material or activity & Sanction \\
\hline Sanofi-aventis & $\begin{array}{l}\text { Fluzone High-Dose } \\
\text { (influenza vaccine) }\end{array}$ & $\begin{array}{l}\text { Product-specific } \\
\text { consumer media release }\end{array}$ & $\begin{array}{l}\$ 100,000 \text { fine } \\
\text { Claims not to be used again }\end{array}$ \\
\hline Seqirus & Fluad (influenza vaccine) & Promotional material & $\begin{array}{l}\$ 40,000 \text { fine increased to } \$ 80,000 \\
\text { on appeal. Corrective letter to } \\
\text { health professionals }\end{array}$ \\
\hline Pfizer & Xeljanz (tofacitinib citrate) & $\begin{array}{l}\text { Promotional banner at } \\
\text { trade display }\end{array}$ & $\begin{array}{l}\$ 25,000 \text { fine } \\
\text { Materials not to be used again }\end{array}$ \\
& Xarelto (rivaroxaban) & Promotional material & $\begin{array}{l}\$ 150,000 \text { fine } \\
\text { Clinical Paper Carrier not to be } \\
\text { used again } \\
\text { Corrective letter to health } \\
\text { professionals }\end{array}$ \\
\hline Eli Lilly & Taltz (ixekizumab) & Professional conduct & \begin{tabular}{l}
$\$ 15,000$ fine \\
\hline
\end{tabular}
\end{tabular}

\section{REFERENCES}

1. Medicines Australia. Code of Conduct. 18th ed. 2015. https://medicinesaustralia.com.au/code-of-conduct/codeof-conduct-current-edition [cited 2020 Nov 1]

2. Medicines Australia. Code of Conduct. 19th ed. 2019. https://medicinesaustralia.com.au/code-of-conduct/codeof-conduct-current-edition [cited 2020 Nov 1]
3. Medicines Australia. Code of Conduct Annual Report 2019 2020. https://medicinesaustralia.com.au/code-of-conduct/ code-of-conduct-reports [cited 2020 Nov 26] 